
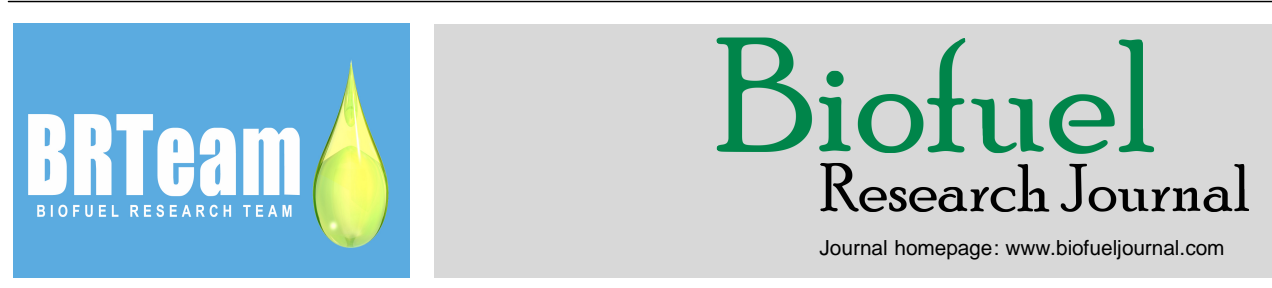

Review Paper

\title{
Genetic modification: a tool for enhancing cellulase secretion
}

Anusuiya Singh ${ }^{1}$, Anil Kumar Patel $^{2}$, Mukund Adsul $^{1}$, Anshu Mathur ${ }^{1}$, Reeta Rani Singhania $^{1, *}$

${ }^{1}$ DBT-IOC Centre for Advanced Bio-Energy Research, Indian Oil Corporation; R\&D Centre, Sector-13, Faridabad-121007, India.

${ }^{2}$ Department of Molecular Biosciences and Bioengineering, University of Hawaii at Manoa, Honolulu 96822 HI, United States.

\section{HIGHLIGHTS}

$>$ Recent advancement on cellulases for $2^{\text {nd }}$ generation bioethanol production through genetic modification has been critically reviewed.

$>$ Various mutation strategies and their prospects towards strain improvement have been summarized.

$>$ Genetic engineering-based advancements for strain improvement has also been covered.

\section{GRAPHICAL ABSTRACT}

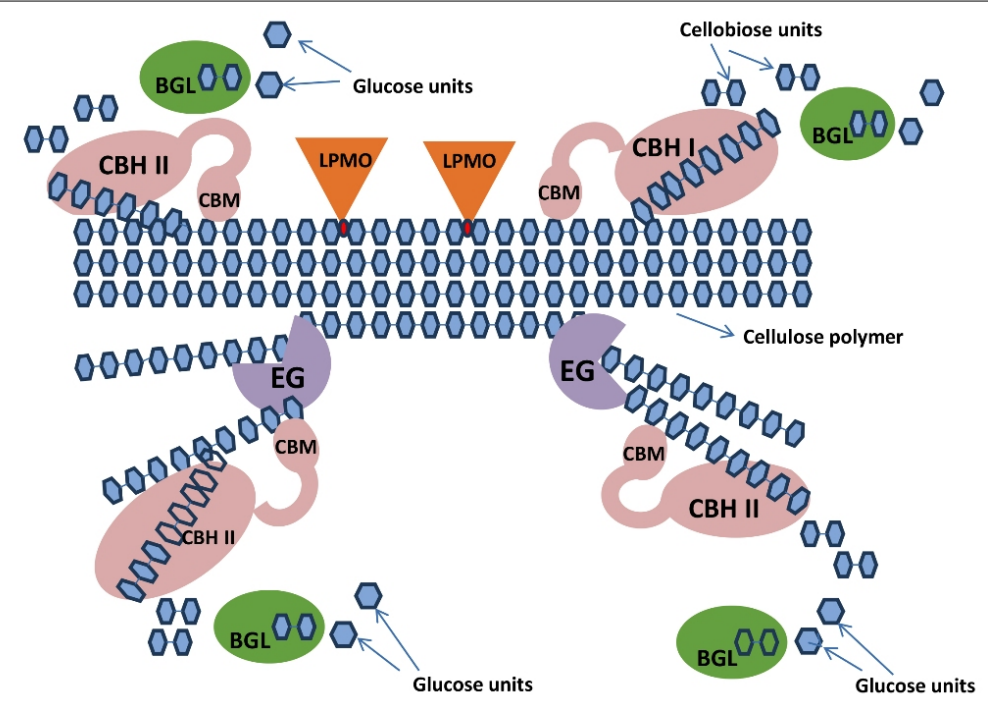

\section{ARTICLE INFO}

\section{Article history:}

Received 15 March 2017

Received in revised form 22 May 2017

Accepted 22 May 2017

Available online 1 June 2017

\section{Keywords:}

Lignocellulosic (LC) biomass

Biological conversion

Cellulase

Genetic engineering

Mutation

\begin{abstract}
Lignocellulosic (LC) biomass is abundantly available as a low-cost resource on the Earth. LC conversion into energy carriers is the most accepted alternative energy production policy because it is non-competitor to food or feed. LC ethanol has brought cellulases to the forefront which was otherwise lost in oblivion during last decades. LC biomass can be converted into value added products or into sugars by various routes, e.g., thermo-chemical, chemical, or biological methods. Biological route via enzymes is one of the most eco-friendly and feasible method. Both fungi and bacteria are known to degrade biomass. Fungi have been greatly exploited for cellulase production due to their inherent properties of secreting extracellular cellulase. These microorganisms are known as cellulase producers for many decades, however, to bring the enzymatic biomass conversion to an economically feasible status, extensive research efforts have been made in last decade to enhance cellulase titers. Mutations and genetic interventions along with bioprocess development have played a very important role for enhancing cellulase production. This review will present a critical overview of the on-going research towards improving cellulase production for biofuel industry via genetic modification, which will include mutation and genetic engineering employed to exert changes at genetic level in microorganisms.
\end{abstract}

* Corresponding author at: Tel.: +91-88 82956561

E-mail address: reetasinghania@gmail.com

Please cite this article as: Singh A., Patel A.K., Adsul M., Singhania R.R. Genetic modification: a tool for enhancing cellulase secretion. Biofuel Research Journal 14 (2017) 600-610. DOI: 10.18331/BRJ2017.4.2.5 


\section{Contents}

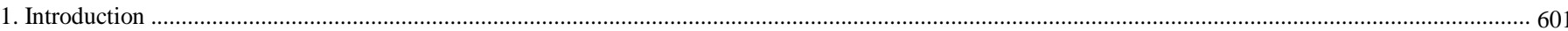

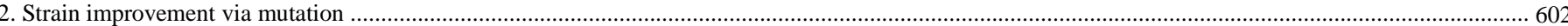

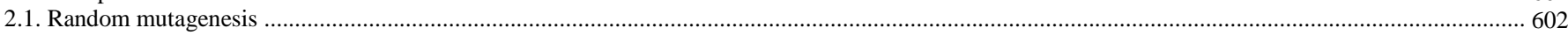

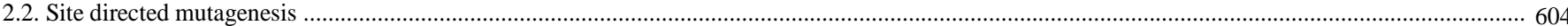

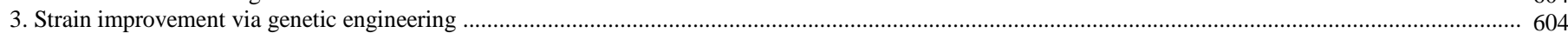

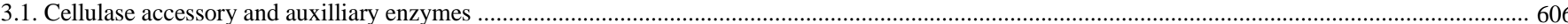

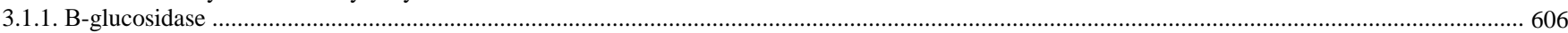

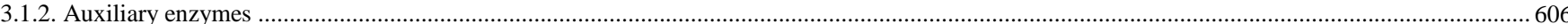

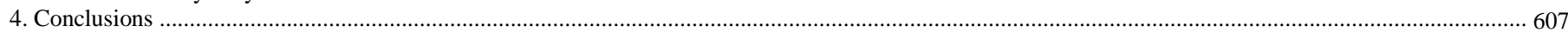

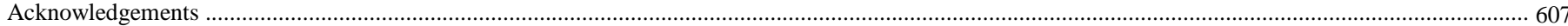

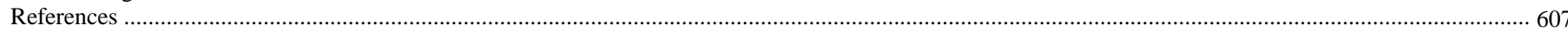

\begin{tabular}{|c|c|}
\hline Abbreviations & \\
\hline A. cellulolyticus & Acremonium cellulolyticus \\
\hline A. nidulans & Aspergillus nidulans \\
\hline A. niger & Aspergillus niger \\
\hline AA & Auxiliary activities \\
\hline BGL & $\beta$-glucosidase \\
\hline C. lucknowense & Chrysosporium lucknowense \\
\hline CAZy & Carbohydrate-active enzyme database \\
\hline CBD & Cellulose binding domain \\
\hline $\mathrm{CBH}$ & Cellobiohydrolase \\
\hline $\mathrm{CBH} \mathrm{I}$ & Cellobiohydrolase I \\
\hline CBM & Carbohydrate binding module \\
\hline $\mathrm{CD}$ & Catalytic domain \\
\hline DNA-SIP & DNA stable-isotope probing \\
\hline EG & Endo- $\beta$-1,4-glucanase \\
\hline EMS & Ethyl methyl sulfonate \\
\hline GC3 & Third nucleotide position \\
\hline LC & Lignocellulosic \\
\hline LPMOs & Lytic polysaccharide monooxygenase \\
\hline M. thermophila & Myceliophthora thermophila \\
\hline NHEJ & Non-homologous end-joining pathway \\
\hline NTG & $\mathrm{N}$-methyl-N'-nitro-N-nitrosoguanidine \\
\hline P. decumbens & Penicillium decumbens \\
\hline P. janthinellum & Penicillium janthinellum \\
\hline P. oxalicum & Penicillium oxalicum \\
\hline P. verruculosum & Penicillium verruculosum \\
\hline REXRN & Reconstruction of Expression Regulatory Network \\
\hline SWO1 & Swollenin \\
\hline T. atroviridae & Trichoderma atroviridae \\
\hline T. reesei & Trichoderma reesei \\
\hline
\end{tabular}

\section{Introduction}

Depletion of fossil fuel resources along with increasing energy demands globally, as well as environmental concerns have collectively raised significant attention towards biofuels as cleaner alternative energy carriers. Lignocellulose biomass (LC) is the most abundant and ubiquitous renewable biomaterial on our planet which makes LC bioconversion very attractive option over other alternative energies. LC contains mainly cellulose (30-50\%), hemicelluloses (20-40\%), and lignin (20-30\%). All these three components are rigidly packed with each other (Fig. 1), protecting them against microbial attacks and consequently making their degradation difficult. Out of the three

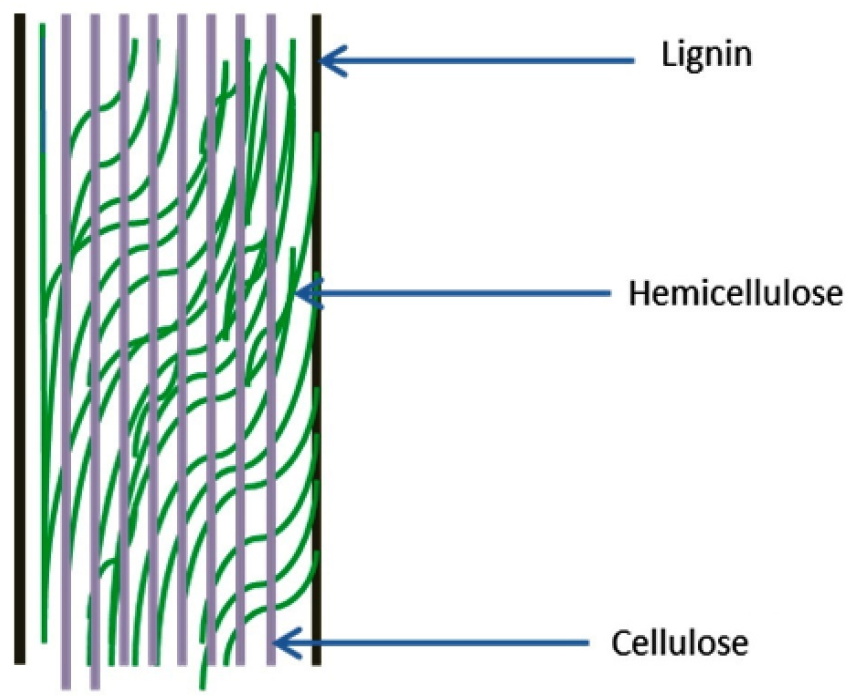

components; cellulose and hemicelluloses can be converted into fermentable sugars which can be further converted into fuels (ethanol) and other value-added chemicals. There are several ways for biomass deconstruction such as thermochemical, chemical, or biological; but the biological route via enzyme is the most popular one, because of being ecofriendly and sustainable. Cellulases and xylanases are capable of degrading biomass into its monomeric sugars to be further fermented into value-added products. Lignin is a major hindrance on the way of efficient hydrolysis of biomass (Saini et al., 2016). It could be partly removed by alkali pretreatment of biomass making cellulose and hemicelluloses accessible to enzymes. Cellulose, constituting a major portion of the biomass, is composed of glucose linked with $\beta, 1-4$ linkage. Cellulases can hydrolyze cellulose into glucose, but rarely cellulose is found in pure form in nature, hence are mostly associated with hemicelluloses and lignin. Along with lignin even hemicelluloses act as a physical barrier for cellulase to access cellulose (Volynets and Dahman, 2011), hence cellulases with xylanases are more effective for biomass degradation. In fact, xylanases hydrolyze hemicelluloses portion making cellulose accessible to cellulase. Hence xylanases when used in combination with cellulases; the cocktail shows synergistic effect releasing more fermentable sugars from the biomass $(\mathrm{Hu}$ et al., 2011).

Microorganisms such as fungi and bacteria are capable of degrading lignocellulosic materials. Filamentous fungi produce large amounts of extracellular cellulases whereas, bacteria as well as few anaerobic fungi produce cellulosomes, a complex of cellulolytic enzymes associated with their cell wall. Cellulolytic enzyme systems are extensively studied in a wide variety of microorganisms, complexed or non-complexed (Lynd et al., 2002), including aerobic and anaerobic bacteria (Gilkes et al., 1991), white rot and soft rot fungi (Wood et al., 1988), and anaerobic fungi (Schwarz et al., 2001). Cellulase is a complex enzyme which consists of endoglucanase, cellobiohydrolase (exoglucanase), and $\beta$-glucosidase working in a synergistic manner to hydrolyze cellulose chains. Fungi such as 
Trichoderma reesei, Penicillium spp., and Aspergillus niger produce large amounts of extracellular cellulolytic enzymes. Higher fungi such as basidiomycetes (e.g., Phanerochaete chrysosporium) having unique oxidative systems in addition to cellulolytic/hemicellulolytic activities, are capable of degrading lignocelluloses through their ligninolytic enzymes (Dashtban, 2009).

Though bacteria and fungi, both are able to produce cellulases, fungi are considered as better candidates for cellulase production due to their capacity to produce large amounts of extracellular cellulases. Cellulases hydrolyze $\beta-1,4-$ D-glucan linkages in cellulose and produce glucose, cellobiose, and cellooligosaccharides. Three types of cellulases which contribute to hydrolysis are (a) cellobiohydrolase $(\mathrm{CBH}) /$ exoglucanase, (b) endo- $\beta$-1,4-glucanase (EG), and (c) $\beta$-glucosidase (BGL). EGs cleave cellulose polymer from in between exposing reducing and non-reducing ends, while $\mathrm{CBH}$ acts upon these reducing and non-reducing ends to release cello-oligosaccharides and cellobiose, and finally BGL cleaves cellobiose to liberate glucose and thus completing the hydrolysis. These three enzymes work synergistically to hydrolyze cellulose (Singhania et al., 2010). Crystalline cellulose hydrolysis is also facilitated by lytic polysaccharide monooxygenase (LPMOs). These are non-hydrolytic proteins, causing nicks on cellulose fibers so as to accelerate the action of endoglucanase. Thus, all these enzyme systems act together in perfect synergism as shown in Figure 2. Majority of cellulases have a characteristic two-domain structure (Ohmiya et al., 1997; Sakka et al., 2000) with a catalytic domain $(\mathrm{CD})$ and a cellulose binding domain [CBD; also called carbohydrate binding module (CBM)) connected through a linker peptide]. Core domain or catalytic domain contains catalytic site whereas CBDs help in binding of enzyme to cellulose. Degradation of native cellulose requires different levels of cooperation between cellulases. Such synergisms exist between endo and exoglucanases (exo/endo synergism) and between exoglucanases. BGL has been regarded as the rate-limiting enzyme as it completes the hydrolysis by hydrolyzing cellobiose which otherwise if remains in the medium inhibits CBHs production (Yao et al., 2015). BGL itself gets feedback-inhibited if glucose accumulates, thus emphasizing on the need to have glucose tolerant BGLs so as to drive reaction forward even in the presence of glucose (Singhania et al., 2013).

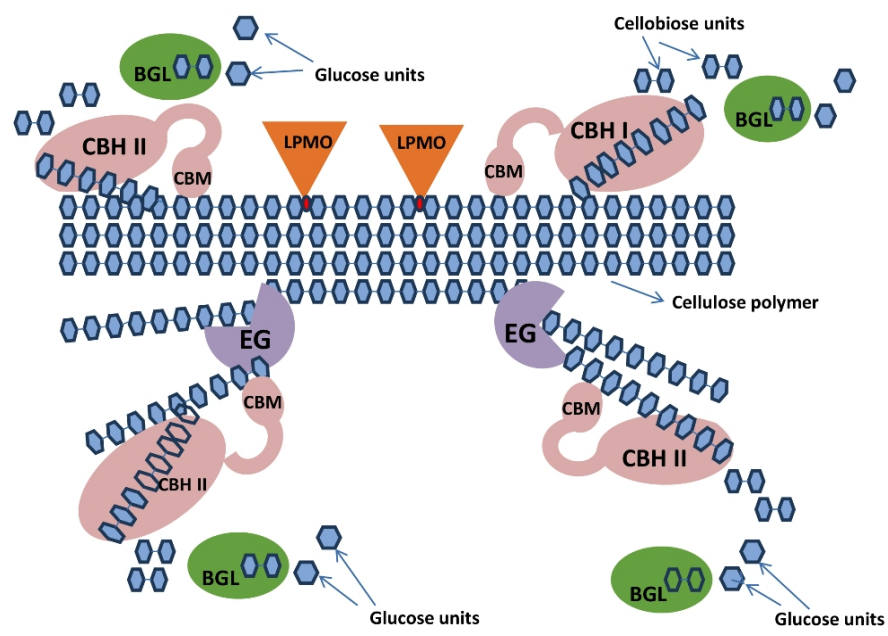

Fig.2. Cellulase components acting in synergism to degrade cellulose polymer

(BGL: $\beta$-glucosidase, CBH: cellobiohydrolase, CBM: carbohydrate binding module, EG: endo$\beta$-1,4-endoglucanase, and LPMO: lytic polysaccharide monooxygenase)

T. reesei is one of the most potent cellulase producers which has been extensively studied and exploited for commercial cellulase production. $T$. reesei cellulases are inducible enzyme whose regulation of production is controlled by activation (Sukumaran, 2008) and repression mechanisms of genes (Ilmen et al., 1997). T. reesei cellulase is rich in CBH and has sufficient EG as well but it is deficient in BGL. Several studies have been performed on improving BGL content of $T$. reesei so as to produce excellent repertoire of cellulase for efficient hydrolysis of biomass. In several cases, heterologous
BGL was overexpressed in T. reesei and was found successful in improving cellulase content (Singhania et al., 2017). Fungal cellulases are thus the most promising candidates and are exploited for improved production (Mathew et al., 2008). Optimization of physical and nutritional parameters have also led to enhanced cellulase production, however, to have further enhancement, strain improvement is inevitable. Strains can be improved by genetic modification to increase their cellulase production as well as their efficiency. In this article, we shall give an account of the mutations as well as genetic engineering approaches which have been carried out by researchers to improve cellulase production.

\section{Strain improvement via mutation}

Strain improvement is inevitable if cellulase production has to be reached to an industrially-feasible level. Engineering the cellulases to improve their properties to meet the robust industrial applications is often required. Filamentous fungi natively secrete various cellulases when growing on lignocelluloses wastes. Improving cellulase expression by random mutagenesis is the classical approach. Random mutagenesis, sitespecific mutagenesis, or their combination have been used to obtain tailormade enzymes for industrial applications (Dalby, 2007). For the last 20 years, Penicillium oxalicum mutant (JU-A10-T) has been used to produce cellulase enzyme preparations at industrial scale in China (Liu et al. 2013a).

\subsection{Random mutagenesis}

T. reesei RUT-C 30 is the result of 30 cycles of random mutation (Peterson and Nevaleinen, 2012). This is of the most exploited fungal strain for commercial cellulase production. The reason for being most exploited is that it has been researched exclusively while other cellulase sources were neglected during earlier days. At present, Penicillium sp., Aspergillus sp. Myeciliophthora, Humicola sp., are considered as tough competitors of $T$. reesei (Javed et al., 2011). Among other methods of strain improvement, classical mutation has been the most accepted till today. Several articles have been published on fungal mutations and thereby increased cellulase production. Most of the fungal strains employed for commercial cellulase production are mutant strains though few are genetically-modified. Table 1 presents the strains with improved cellulase production through mutation. As mentioned earlier, most of the industrially-exploited strains for cellulase production are robust mutants.

Major producers of fermentation products extensively utilize mutation and selection. The production of cellulases by the microbial cells is generally regulated by genetic and biochemical approaches that include induction and catabolite repression, or end product inhibition. These approaches are operative under cellulase production conditions, thus resulting in limited yields of the enzymatic constituents. The first catabolite repressed in Bacillus pumilus through mutagenesis led to cellulase yields four times higher than the wild type strain (Kotchoni et al., 2003). T. reesei Qm 6a, a wild type strain isolated at the US Army Natick Research and Development Command, Natick, USA, was mutated in 'Rutgers university' and resulted in the strain RUT-C30 (where "RUT" stands for Rutgers) showing 20 times increase in cellulase secretion. (Mandel and Weber, 1971; Eveleigh and Montenecourt, 1979). Although the gold standard for cellulase production in industry was reported to be higher than $100 \mathrm{~g} / \mathrm{L}$, this strain is still the prototype cellulase hyperproducer available to the public domain (Peterson and Nevalainen, 2012) with titers of extracellular protein reaching $30 \mathrm{~g} / \mathrm{L}$ on the cellulase inducing substrate lactose (Durand et al., 1988). There are several fungal species which were improved via mutation (Table 1). A hypercellulolytic mutant NTG-19 from Fusarium oxysporum was developed by Kuhad et al. (1994) by ultraviolet treatment followed by chemical mutagenesis using $\mathrm{N}$-methyl- $\mathrm{N}$ '-nitro- $\mathrm{N}$-nitrosoguanidine (NTG). The resultant mutant strain had substantially higher $(80 \%)$ cellulolytic activity than its parent strain. NTG treatment of Cellulomonas xavigena also produced four mutants (M4, M9, M11, and M12) with improved xylanolytic activities (Mayorga-Reyes and Ponce-Noyola, 1998). A mutant creAd3 with the end product inhibition resistance and improved levels of D-glucose metabolism was constructed from Aspergillus nidulans (Veen et al., 1995). Chand et al. (2005) and Vu et al. (2009) introduced new methods for fungal mutation to obtain stable mutants; i.e., 
Table 1.

Cellulase production improvement via mutagenesis among microorganisms.

\begin{tabular}{|c|c|c|c|}
\hline Microorganism & Type of mutation & Recombinant properties & References \\
\hline Pencillium oxalicum & Functional mutation & Enhanced cellulase production (160 FPU/L/h) & Liu et al. (2013b) \\
\hline Aspergilus species & Sequential random mutation & Enhanced cellulase production & Vu et al. (2009) \\
\hline Acremonium cellulolyticus & Random mutation & Enhanced $\beta$-glucosidase activity and FPase activity & Fujii et al. (2013) \\
\hline Cellulolytic fungi & Random mutation & Stable and enhanced cellulase production & Chand et al. (2005) \\
\hline Penicillium janthinellum NCIM1171 & Random mutation & Enhanced cellulase production and hydrolysis & Adsul et al. (2007) \\
\hline Trichoderma atroviride & Random mutation & Enhanced cellulase production & Li et al. (2010) \\
\hline Humicola insolens & Random mutation & Enhanced cellulase production & Irfana (2011) \\
\hline Aspergillus sp. Su14 & Random mutation & Enhanced cellulase production & Vu et al. (2011) \\
\hline Penicillium decumbens 114 & Random mutation & Enhanced cellulase and hemicellulase production & Liu et al. (2013a) \\
\hline Trichoderama viride & Random mutation & Enhanced cellulase production & Li et al. (2010) \\
\hline Aspergillus terreus AUMC 10138 & Random mutation & Enhanced alkaline cellulase production & Isaac et al. (2015) \\
\hline Fusarium oxisporium & Random mutation & Enhanced cellulase production & Kuhad et al. (1994) \\
\hline Cellulomonas & Random mutation & Enhanced xylanolytic activity & Mayorga-Reyes and Ponce-Noyola (1998) \\
\hline P.funiculosum & Site directed mutagenesis & Increased enzyme activity against crystalline cellulose & Adney et al. (2009) \\
\hline Thermotoga maritima & Site directed mutagenesis & Increased thermostability and activity towards avicel & Mahadevan et al. (2008) \\
\hline Macrophomina phaseolina & Site directed mutagenesis & Modified endoglucanase for hydrolysis of $\beta$-glucans & Wang et al. (1997) \\
\hline
\end{tabular}

continuous application of mutagen at sub lethal concentrations and repeated and sequential mutagenesis, respectively. Overall, fungal mutation has been done by exposing mycelia (Fujii et al., 2013) as well as spores (Chand et al, 2005; Adsul et al., 2007) to the mutagen and both ways have been successful. $P$. janthinellum when treated with ethyl methyl sulphonate and ultraviolet light produced a stable mutant $P$. janthinellum EU1 leading to 2 times higher cellulase activity (Adsul et al., 2007).

Fujii et al. (2013) mutated Acremonium cellulolyticus which has emerged as potent cellulase producing filamentous fungus. A. cellulolyticus wild strain secrets large amounts of cellulolytic enzymes compared with $T$. reesei. It was mutated by random sequential mutagenesis by exposing mycelia to UV and then to NTG. Mutant strain CF2612 exhibited greater FPase activity (17.8 $\mathrm{U} / \mathrm{mL}$ ) than its parent by $50 \%$. In addition, $\beta$-glucosidase activity and soluble protein production were also improved in the mutant. In 5\% Solka Floc, the mutant s productivity stood at $150 \mathrm{FPU} / \mathrm{L} / \mathrm{h}$ in a jar fermenter in batch mode. The enzyme produced was superior in terms of efficiency as confirmed by producing higher hydrolyzed sugars from pretreated eucalyptus.

Similarly, T. atroviridae was mutated using NTG and UV light exposure sequentially and the mutant produced higher cellulases as well as $\beta$ glucosidases compared with the parent strain (TUB F 1505 which was identified as T. atroviridae) as well as T. reesei RUT-C30 (Kovacs et al., 2008). It was shown that hydrolysis of pretreated willow by enzyme broth of mutant did not require supplementation of $\beta$-glucosidases for higher glucose production unlike $T$. reesei RUT-C30 and the parent enzyme broth. There are reports on mutation of Penicillium strains too presenting tough competitions to Trichoderma strain for cellulase production. The strain $P$. janthinellum NCIM1171 was exposed to mutagen ethyl methyl sulfonate (EMS) and UV radiation sequentially. Mutants were selected based on halo zones on walseth cellulose agar plate containing $1.5 \%$ 2-deoxy-D-glucose. The best mutant showed 2 folds enhancement in FPase and CMCase compared with the parent strain (Adsul et al., 2007).

A strain of Aspergillus was exposed to sequential treatments of $\gamma$-irradiation of Co60, ultraviolet, and NTG treatment. Mutant Aspergillus sp. XTG-4 was consequently obtained which produced $2.03-, 3.20-$, and 1.80 -fold higher CMCase, FPase, and $\beta$-glucosidase, respectively, when compared with the wild type strain. Mutant strain was sub-cultured 19 times hence concluded that the mutant Aspergillus sp.XTG-4 was stable (Vu et al., 2009). In a different study, the spores of Aspergillus sp. Su14 was exposed to Co60 $\gamma$-rays, ultraviolet, and NTG repeatedly and sequentially to undergo mutation. One mutant was selected, i.e., Aspergillus sp. SU14-M15 whose cellulase yield was increased by 2.2 folds as compared with its parent (Vu et al., 2011). After optimizing conditions for the production of cellulase by the mutant strain using solid state fermentation; cellulase yield was reportedly enhanced by 8.5 folds as compared with the wild type strain (Vu et al., 2011).

T. viride is a potent CMCase producer and to further enhance it, strain improvement via random mutation was varied out by Li et al. (2010). Accordingly, the strain was exposed to physical mutagen such as microwave and ultraviolet. As a result of the mutagenesis, seven different mutants were selected (M-B1 to M-B7) out of which 5 were reported to have stronger ability to produce enzymes than the parent strain. Screening was on the basis of CMCase activities and the mutants were reported to be stable up to 9 generations. Molecular studies indicated that the base of endoglucanase gene was mutated in M-B1, M-B2, M-B3, and M-B5 mutants but no changes in M-B7 were observed, concluding that base mutation could lead to the enhancement of cellulase production ( $\mathrm{Li}$ et al. 2010).

Though the above-mentioned studies show enhancements in cellulase production by mutation but they did not discuss the changes that might have actually occurred at genetic level. Liu et al. (2013b) sequenced and compared Penicillium decumbens (which was later identified as $P$ oxalicum) mutant JU-A10-T gene with the wild strain 112-2; transcriptomes and secretomes were also compared. P. oxalicum was selected for its strong cellulolytic ability in saprophytic condition. Whole genome sequencing was conducted and it was revealed that the fungus obtained a unique lignocellulose-degrading enzyme arsenal during evolution. Comparative genomic analysis of $P$. oxalicum and other cellulolytic fungus was also performed and it was observed that this fungus had a higher number and more types of genes encoding hemicellulases, as well as genes encoding CBM containing proteins, than the other cellulolytic fungi, such as T. reesei and A. niger.

$P$. oxalicum, and other species of Pencillium exhibits higher $\beta$ glucosidase activity than $T$. reesei. Random mutagenesis was successfully applied on $P$. oxalicum for improved cellulase production. One of these mutants, JU-A10-T, with a maximum volume productivity of $160 \mathrm{U} / \mathrm{L} / \mathrm{h}$, was developed and utilized at industrial scale cellulase production since 1996 in China. Liu et al. (2013a) did repeated mutation of $P$. oxalicum resulting in increased production of cellulases and hemicellulases. It was observed that not all proteins were secreted by the mutant and that they only produced cellulases and hemicellulases in high levels, making it a specific producer of lignocellulolytic enzymes. Functional analysis also concluded that there were changes in several transcriptory regulatory elements which played important role in hyper production of cellulases in the mutant. It was also observed that the mutant showed enhanced supply of amino acids 
whereas decreases in the synthesis of secondary metabolites as compared with wild type were noticed. From the above observation, one can conclude that gene regulators and promoters could be targeted with minimum changes in the genetic content. Thus, there must be a maximum emphasis on genetic engineering (Liu et al., 2013a).

\subsection{Site directed mutagenesis}

When mutagenesis is done to bring the desired changes in the DNA sequences of a gene, it is called site directed mutagenesis. It is time consuming as one should know the sequence of a given genome and the region to target. Then, with help of specific primers amino acid sequence can be changed and subsequently, by homologous recombination, the changes will be incorporated to the genome to cause the desired changes in the properties of the target protein. So, in another word, site directed mutagenesis is usually done to improve the properties of a protein by changing its amino acid sequence.

To increase the thermostability of xylanase from A. niger BCC14405, serine and threonine residues on the ser/thr surface of xylanase were replaced with four and five arginines. The modified enzyme showed maximal activity as compared with the wild type strain while the half-life of the mutant enzyme was also increased, i.e., $257 \pm 16$ and $285 \pm 10 \mathrm{~min}$ for the four- and five-arginine mutants, respectively, vs. $14 \pm 1$ min for the wild enzyme (Sriprang et al., 2006). Therefore, it could be concluded that arginine substitution increased stability by $18-20$ folds. Kinetics study was also conducted and five arginine substitution enzyme showed lower substrate affinity and catalytic rate (Sriprang et al., 2006). An endoglucanase from Thermotoga maritime cel5A underwent site directed mutagenesis and CBM engineering to obtain a hyperthermostablity (Mahadevan et al., 2008). For this, amino acids in the active sites were targeted. A shift in the $\mathrm{pH}$ from 5.0 to 5.4 was observed in five single mutants. One of them showed $10 \%$ higher activity when compared with the native cel5A. Domain engineering was done with fungal and bacterial CBM. Further to this, CBM1 from (CBH II) $T$. reesei and CBM6 from Clostridium stercorarium xylanase A were integrated with cel5A. Higher hydrolytic activity was observed on avicel by both CBM-engineered cel5A. Immuno-gold labeling assay was also performed and it was observed that there was a correlation between binding ability and activity (Mahadevan et al., 2008).

Fungus Macrophomina phaseolina produced EG, while some conserved regions in this enzyme family were modified through site-directed mutagenesis resulting in the production of an enzyme which required a novel substrate (Wang et al., 1997). In fact, D232A lying within the substrate-binding cleft of EG, was mutated to generate the engineered form. When compared; it was observed that wild-type EG required a minimum substrate size of 5 glucosyl units whereas the engineered form required a minimum of 6 glucosyl units. Both wild type and mutated Egl1 were shown to possess an equivalent activity on cellohexaose and also released cellobiose from reducing end of cellodextrin. This modified EG can be useful for the hydrolysis of complexed carbohydrates such as $\beta$-glucan (Wang et al., 1997).

Industrial cellulase preparations produced by fungal mutant strains has tremendous applications in the growing biotechnology of manufacturing second-generation biofuels from lignocellulosic residues (Gusakov, 2013). Therefore, much attention is now focused on finding cellulases with higher specific activity, better stability, lower susceptibility to inhibition, as well as improved properties vs. the already known enzymes, using modern genetic engineering techniques (Voutilainen et al., 2008; Gusakov, 2011; Bommarius et al., 2014; Gusakov, 2014; Trudeau et al., 2014). With the progress in heterologous expression, production systems of recombinant enzymes have proved to be promising platforms to efficiently produce industrial cellulase (Garvey et al., 2013).

\section{Strain improvement via genetic engineering}

Genetic engineering is one of the most popular tool which has enabled researchers to combine multiple desirable traits into a single organism. It can be used to engineer microbes for high metabolite production which could vary from simple proteins to highly specific therapeutic proteins. However, it may not be as simple as it sounds because of the inherent complexity of the organisms itself or the metabolites needed to be expressed. The most important information which is required is the genetic makeup of the organisms. Knowledge of whole genome sequence and functions makes it easier to decide the target sites for genetic alterations.
Targeted strain engineering towards improved cellulase production in fungi or for metabolic engineering requires efficient methods to introduce directed genetic alterations into an organism. The generally low efficiency of gene targeting has for a long time been a major challenge to obtain a reasonable number of transformants by homologous integration or a deletion of expression cassette. This is mostly due to the complexities associated with the presence of introns in the respective genes and due to complexities associated with glycosylation. Filamentous fungi are known to produce a broad range of metabolites at significant quantities. Their ability to grow on cheaper substrate have made them potential sources of metabolites for industrial applications. Knowledge of fungal genetics has accumulated since years of research and industrial applications. Along with the ability to secrete proteins, fungi can also perform post transtlational modification such as glycosylation and disulfidation (Wang et al., 2005). Most of the filamentous fungi are transformed with plasmid which integrates into their genome, thereby providing stability to the funga transformants. Thus, filamentous fungi have tremendous potential to be employed as hosts for recombinant DNA. But there exist challenges on nonhomologous recombination in fungi. This problem has been resolved by inactivating components of non-homologous end-joining (NHEJ) pathway of DNA repair (Guangtao et al., 2009; Steiger et al., 2011). Genus Aspergillus and strain $T$. reesei have been used as hosts for expressing several genes of fungal as well as nonfungal origin. Table 2 gives an account of the heterologous gene expression for improving cellulase production as well as the ratio of different components to increase its efficiency.

Genome sequencing of $T$. reesei (Martinez et al., 2008) revealed that despite being the best-known producer of cellulases; the genome of the fungus contains fewer cellulases and hemicellulases genes than any other sequenced fungi. Thus, the mechanism and reason for high secretion leve is still to be revealed. It has been observed that cellulase and hemicellulase genes of filamentous fungi $T$. reese $i$ is under carbon catabolite repression mediated by the regulatory gene cre1. In a study by Nakari-Setala et al. (2009), this gene, e.g., crel was completely removed or replaced by a truncated mutant variant, i.e., the cre $1-1$ which was previously found in RUT-C30 mutant strain with enhanced enzyme production. This resulted in morphological changes in the colony of the mutants as compared with the wild strain. More specifically, the colonies become smaller in size and had fewer aerial hyphae and spores. When cultured in glucose-rich medium, these transformants showed increased cellulase and hemicellulase production. They also showed elevated levels of hydrolytic enzymes when cultured in fermentation media inducing the hydrolase genes. The findings of this study revealed that crel acts as a modulator of genes expressing cellulase and hemicellulase under both inducing and non-inducing conditions. When different experiments on the mutant strains with crel and cre1-1 were performed, no phenotypic differences were reported, marking that cre 1-1 gene as a null allele. Overall, the authors argued that cre 1 could serve as a valid target gene in engineering of $T$. reesei for improved enzyme production (Nakari-Setala et al., 2009).

In cellulolytic fungi, induction and repression mechanisms synchronously regulate the synthesis of cellulolytic enzymes for accurate responses to carbon sources in the environment. Many proteins, particularly transcription regulatory factors which are responsible for these processes, were identified and genetically-engineered in $P$. oxalicum and other cellulolytic fungi, but in spite of all these great efforts, modifying a single target for the production of cellulase is still limited.

For improving lignocellulolytic enzyme production, a systematic approach was developed for genetically modifying P. oxalicum. Clr-2 is the fungal specific transcription factor domain-containing protein and is also known as cellulose degradation regulator. In Neurospora crassa, out of 212 genes responding to avicel, 135 were found regulated by $\mathrm{Clr}-1 / \mathrm{Clr}-2$ (Coradetti et al., 2012). Its ortholog in P. oxalicum is $c l r B$ which is essential for inducing cellulase expression and is conserved in ascomycete fungi, therefore, first target level of $\operatorname{clr} B$ was increased constitutively by over expressing the gene with the promoter gpdA from A. nidulans. Major intracellular $\beta$-glucosidase plays a negative role in the induction of cellulases and xylanases. In addition to this, the expression of cellulases and hemicellulases were repressed when the preferred carbon sources were available, which is mediated by transcription factor CreA. To overcome repression, gene $b g l 2$ was replaced by marker gene $h p h$ along with $\operatorname{clr} B$ 
Table 2.

Heterologous expression for enhanced cellulase production.

\begin{tabular}{|c|c|c|c|c|}
\hline Source & Host & Strategy used & Recombinant properties & References \\
\hline $\begin{array}{l}\text { Promoter gpdA from Aspergillus } \\
\text { nidulans }\end{array}$ & Pencillium oxalicum & $\begin{array}{l}\text { Amplifying induction along with depression } \\
\text { (knock out strategy) }\end{array}$ & Enhancement of cellulase production & Yao et al. (2015) \\
\hline Pencillium decumbens & $\begin{array}{l}\text { Trichoderma reesei } \\
\text { (RUT-C-30) }\end{array}$ & Agrobacterium mediated transformation & Enhanced $\beta$-glucosidase activity & Ma et al. (2011) \\
\hline $\begin{array}{l}\text { E coli } \beta \text {-glucosidase and acetamidase } \\
\text { gene }(\text { amd } S) \text { or the } \arg B \text { gene of } A \text {. } \\
\text { nidulans }\end{array}$ & T. reesei & $\begin{array}{l}\text { Transformation via plasmid carrying selectable } \\
\text { marker }\end{array}$ & $\begin{array}{l}\text { Enhanced cellulase production with higher } \\
\text { BGL content }\end{array}$ & Penttilä et al. (1987) \\
\hline $\begin{array}{l}\text { Chymosin (rennin) isolated from } \\
\text { stomach of young calves }\end{array}$ & T. reesei & $\begin{array}{l}\text { Transformation via plasmid constructed by } \\
\text { Prochymosin cDNA fused with promoter, signal } \\
\text { sequence, and terminator of the } c b h l \text { gene }\end{array}$ & $\begin{array}{l}\text { Production of eukaryotic heterologous } \\
\text { protein for enhanced cellulase production. }\end{array}$ & Uusitalo et al. (1991) \\
\hline Expression vector PAMH10 & T. reesei & $C B H^{\mathrm{g}}$ ene inactivation & Enhanced cellulase production & Harkki et al. (1991) \\
\hline Myceliophthora thermophila & Pichia pastoris & Cloned and expressed $e g 7$ & Thermostable cellulase & Karnaouri et al. (2014a) \\
\hline Penicillium funiculosum NCL1 & P. Pastoris & Cloned and expressed $b g l$ & Glucose tolerant BGL & Ramani et al. (2015) \\
\hline Penicillium oxalicum & P. oxalicum & $\begin{array}{l}\text { Overexpressed BGL under constitutive and } \\
\text { inducible promoter }\end{array}$ & $\begin{array}{l}65 \text { folds higher yield compared with wild } \\
\text { type }\end{array}$ & Yao et al. (2016) \\
\hline $\begin{array}{l}\text { bgl from Aspergillus niger } / \operatorname{Tr} L P M O \\
\text { from T. Reesei }\end{array}$ & P. verruculosm & $\begin{array}{l}\text { Heterologous expression of } b g l \text { and lpmo under } \\
\text { the control of gla } 1 \text { promoter }\end{array}$ & $\begin{array}{l}\text { Production of heterologous enzyme } \\
\text { simultaneously. }\end{array}$ & Bulakhov et al. (2017) \\
\hline RUT-C-30 & T. reesei & Gene cre 1 knocked out and replaced by a cre $1-1$ & Enhanced cellulase production & Nakari-Setala et al. (2009) \\
\hline AN3046LPMO from A. nidulans & A. nidulans & $\begin{array}{l}\text { Cloned and expressed in protein secreting vector } \\
\text { pEXPYR using ligation free cloning }\end{array}$ & $\begin{array}{l}\text { Enhanced LPMO level in cellulase } \\
\text { produced }\end{array}$ & Jagadeeswaran et al. (2016) \\
\hline
\end{tabular}

over expression while gene $\mathrm{CreA}$ was deleted by using gene bar as the marker, obtaining a trigenic recombinant strain 'RE 10 '. Several screenings were performed for comparative analysis of 'RE 10', wild type, and JU-A10-T, showing considerably improved cellulolytic ability and higher cellulase expression and secretion of 'RE 10' vs. the wild type (Yao et al., 2015). Interestingly, the cellulolytic ability of the mutant was comparable with that of the industrial strain $P$. oxalicum mutant (JU-A10-T).

Creating fungal strain overexpressing positive regulatory genes and knocking out negative regulatory genes would improve cellulase expression. For the last 20 years, $P$. oxalicum mutant (JU-A10-T) has been the core of cellulase enzyme preparations at industrial scale in China (Liu et al., 2013a). Recently, its genome was sequenced, providing valuable information to mine novel components that play key roles in biomass saccharification (Liu et al., 2013b). Furthermore, the signal transduction, inducer transportation, and transcription regulation mechanism of the cellulase gene expression of $P$. oxalicum has been partially uncovered. The sequenced genome, high-efficient gene knock-out techniques, and system biology (RNA-seq and proteomics) are the methods that have led to such an advance. Gene disruption analysis allowed the identification of the three major cellodextrin transporters, i.e., CdtC, CdtD, and CdtG, that play crucial roles in cellulase induction (Li et al., 2013b). Hu et al. (2013) revealed that the G protein-cAMP signaling pathway downregulates the expression of cellulolytic genes. Furthermore, a single-gene deletion library has been established for 470 transcription factors as well as 15 novel and 4 major transcriptional regulators. Their roles in the cellulase expression regulatory network have been identified and characterized (Li et al., 2015). The Reconstruction of Expression Regulatory Network (REXRN) technology has been developed as a new strategy to engineer fungi that enhance cellulase and protein production. As mentioned earlier, mutants in particular, RE 10 developed through REXRN, displayed a drastic increase in cellulase and hemicellulase production, producing comaparble values $v s$. the industrial strain JU-A10-T (Yao et al., 2015). However, the $\beta$-glucosidase of RE 10 has not yet been improved to the same level as other inducible cellulases. This makes further improvement of its $\beta$-glucosidase activity necessary. Yao et al. (2016) have presented a systematic over-expression analysis of nine $\beta$-glucosidase encoding genes in the wild-type strain 114-2 of $P$. oxalicum. They overexpressed BGL1, BGL4, or BGL5 using both constitutive as well as inducible promoters. High yielding $\beta$-glucosidase producers were obtained and the yields were elevated by $2-65$ folds.

Cellulolytic enzyme production could be improved significantly by gene inactivation and changing promoters. Promoter of the cellobiohydrolase I gene $(C B H I)$ is reported as a strong and highly inducible promoter. This promoter is also being used in the eukaryotic heterologous production of protein in T. reesei (Uusitallo et al., 1991). Proportion of different cellulases produced by hypercellulolytic $T$. reesei mutant strain was modified by genetic engineering. An expression vector pAMH110, containing the $C B H$ $I$ gene's promoter and terminator sequences, was used to overexpress a cDNA coding for endoglucanase I (EG), the major endoglucanase $(1,4-\beta$ D glucan glucanohydrolase EC 3.2.1.4). An in vitro modified cDNA which was not capable of coding active enzymes, were also used to inactivate major cellobiohydrolase (1,4- $\beta$-D glucan glucanohydrolase EC 3.2.1.4) gene. This resulted in strains producing higher amounts of specific EG and/or strains lacking the major cellobiohydrolase (Harkki et al., 1991).

$\mathrm{CBHs}$ are usually glycosylated like other fungal enzymes. As a rule, the $\mathrm{N}$-glycosylation is a characteristic of catalytic domains $(\mathrm{CD})$, while peptide linkers, rich in Ser and Thr residues, are heavily decorated with O-linked glycans (Beckham et al., 2012; Payne et al., 2013; Greene et al., 2015). Nlinked glycosylation, is the attachment of an oligosaccharide molecule, known as glycan to a nitrogen atom (amide nitrogen of Asn residue of a protein), in a process called N-glycosylation. This type of linkage is important for structure and function of some eukaryotic proteins. The roles of $\mathrm{N}$ - and $\mathrm{O}-\mathrm{glycosylation}$ in the structure and function of cellulases were not well understood until recent years. It has been thought that both types of glycans may participate in correct folding of a protein and maintaining its stability, while the O-linked glycans in a linker may protect it against protease action (Beckam et al., 2012; Greene et al., 2015). One study has reported that an over- $\mathrm{N}$-glycosylated recombinant $\mathrm{CBH}$ I of $T$. reesei ( $\mathrm{rTrCel7A}$ ) expressed in A. niger displayed a reduced activity on cellulose relative to the native enzyme (Jeoh et al., 2008). Then, the same team of researchers showed that eliminating an existing $\mathrm{N}$-glycosylation site in rTrCel7A or introducing a new N-glycosylation site in recombinant Cel7A of Penicillium funiculosum (rPfCel7A) by site-directed mutagenesis led to an increased enzyme activity against crystalline cellulose (Adney et al. 
2009). Gusakov et al. (2017) applied this approach for boosting the specific activity of recombinant CBH I from Penicillium verruculosum (rPvCel7A expressed in Penicillium canescens) and showed that the $\mathrm{N}$-linked glycans were involved in complex interactions with a polymeric substrate in catalysis confirming previous findings by Dotsenko et al. (2016).

Gusakov et al. (2017) demonstrated by site directed mutagenesis that the Nlinked glycans in the CD of recombinant $P$. verruculosum $\mathrm{CBH}$ II (rPvCel6A) represented an important part of the enzyme processive catalytic machinery. These data, together with their previous data on the highly active CBH IIb (MtCel6B) from Myceliophthora thermophila (formerly Chrysosporium lucknowense) (Gusakov et al., 2007), indicated that the mechanism of the $\mathrm{N}$ glycan influence seems to be universal both for GH6 and GH7 processive CBHs.

\subsection{Cellulase accessory and auxiliary enzymes}

\subsubsection{B-glucosidase}

Most of the potent cellulase producing fungi lack one or the other components of cellulase required for efficient breakdown of cellulose fibers. It is required for a deficient enzyme to be supplemented so that all the components are in optimum concentrations. There is a possibility that a deficient component be over-expressed in base enzyme producing organism to get desired cocktail with all the components of cellulases. The selection of enzyme component to be expressed/over-expressed is usually based on the absence of that enzyme component in base preparations. Most of the commercial cellulase production is being done by recombinant fungal strains. Novozyme Inc. (http://www.novozymes.com/en) used $T$. reesei as parent or base strain and isolated effective cellulolytic as well as non-cellulolytic genes from other organism and transformed them into this strain for effective preparation of enzyme mixture in a single organism (McFarland, 2007). Similarly, Dyadic's strain was also a recombinant which produced few accessory enzymes. Cofermentation of $P$. verruculosum (basic strain) with another $P$. verruculosum with heterologously-expressed Aspergillus $s p$. $\beta$-glucosidase produced up to $19 \%$ of $\beta$-glucosidase as compared with $4 \%$ in the basic strain alone. This cofermented enzyme preparation led to $113 \%$ increased hydrolysis of avicel than the basic strain enzyme preparation (Dotsenko, 2015). In another report, the enzyme preparations produced by recombinant $P$. verruculosum strains, expressing the heterologous AnBGL (BGL from A. niger) or TrLPMO LPMO from $T$. reesei under the control of the gla1 (glucoamylase) gene promoter in a starch-containing medium, proved to be more effective in hydrolysis of a lignocellulosic substrate than the control enzyme preparations without the heterologous enzymes. The enzyme composition containing both AnBGL and TrLPMO demonstrated the highest performance in lignocellulose hydrolysis, providing a background for developing a fungal strain capable of expressing both heterologous enzymes simultaneously (Bulakhov et al., 2017).

The $b g l$ genes from a large number of bacterial, mold, yeast, plant, and animal systems have been cloned and expressed in both E. coli and eukaryotic hosts such as S. cerevisiae, Pichia stipitis and filamentous fungi. In this article we shall deal with microbial sources as well as bgl from metagenomes. Filamentous fungi are known to be a good BGL producer and a number of BGLs from glycosyl hydrolase family 3 and 1 have been purified and characterized from various fungi. In spite of being good producers of the enzyme, reports on cloning of the genes encoding BGL from fungi are relatively low due to complexities. Even Pichia and Saccharomyces have also been employed as host to express eukaryotic bol genes. But several thermotolerant BGLs from bacteria have been cloned and expressed in E. coli.

A $\beta$-glucosidase I coding sequence from $P$. decumbens was ligated with the $\mathrm{CBH} 1$ promoter of $T$. reesei which is widely used in enzyme industry to enhance $\beta$-glucosidase activity in $T$. reesei to degrade cellulose efficiently (Ma et al., 2011). More specifically, the ligated sequences of $\beta$-glucosidase I coding sequence and CBH I promoter sequence were introduced into the genome of $T$. reesei RUT-C-30 through Agrobacterium-mediated transformation. Two transformed strain were selected based on their $\beta$-glucosidase activity and filter paper activity, which were respectively, 6-8 and 30 folds higher compared with the wild strain. Furthermore, heterologously expressed pBGL1 was purified and added to enzyme complex secreted by $T$. reesei RUT-C30 and was observed that during saccharification of pretreated cornstalk, the yield of glucose increased by up to $80 \%$. This result showed that heterologous expression of a BGL in $T$. reesei could produce a balanced cellulase blend (Ma et al., 2011).

Transformation was done in cellulolytic filamentous fungus T. reesei with the help of a plasmid carrying a dominant selectable marker; the acetamidase gene ( $a m d S$ ) or the $\arg B$ gene of $A$. nidulans, complementing respective $\arg B$ mutation of $T$. reesei. Transformation frequency reached up to 600 transformants per pg of transforming DNA. Co-transformed unselected DNA efficiency was high (approx. 80\%). Transformed DNA was found integrated at different locations, often in multiple tandem copies in the $T$. reesei genome. In addition to this, the E. coli $\beta$-glucosidase was expressed in $T$. reesei in enzymatically-active form from the A. nidulans 's gpd promoter (Penttilä et al., 1987).

The complete depolymerization of cellulose polymer needs the synergistic action of three principle cellulases. The use of whole cell cultures is a good option. It confers multiple advantages such as decreases in the enzyme production cost, possibility for expressing complete spectrum of enzymes, and relatively simple scale-up process for bulk and fine chemical production (Fukuda et al., 2009). Therefore, a whole cell engineering of filamentous fungi for elevated cellulase expression is an ideal choice.

\subsubsection{Auxiliary enzymes}

Swollenin (SWO1) is an important protein, which contains N-terminal CBM linked to a C-terminal expansin-like domain (Saloheimo et al., 2002). T. reesei s SWO1 showed a unique mode of action having similarities with action of both endoglucanases and cellobiohydrolases (Andberg et al. 2015). However, SWO1 does not possess hydrolytic activity in itself Gourlay et al. (2013) showed that during enzymatic hydrolysis of pretreated corn stover SWO1 synergistically enhanced endoxylanase rather than endoglucanase or cellobiohydrolase activity. This would be because SWO1 rendered xylan portion of lignocellulose more accessible for degradation by xylanases, thereby indirectly exposing cellulose to the cellulases.

In recent years, LPMOs discovery has been regarded as the biggest revolution in cellulose degradation. Recently, some research has been carried out on the role of non-hydrolytic auxiliary enzymes involved in cellulose hydrolysis and instead of endo-exo synergism, the LPMOs were used in solubilization of crystalline cellulose by oxidative cleavage of glycosidic bonds. LPMOs enhance the saccharification by providing new sites for cellobiohydrolases and $\beta$-glucosidase actions. These enzymes introduced a new, oxidative mechanism to polysaccharide degradation. In cellulose degradation, it is assumed that LPMOs act on the surface of crystalline cellulose fibrils, thereby rendering them more accessible to cellulases (Harris et al., 2010; Levasseur et al., 2013; Eibinger et al., 2014). Intriguingly, these enzymes can derive the electrons needed for this process from lignin via long-range electron transfer (Westereng et al., 2015). In the carbohydrate-active enzyme (CAZy) database, the LPMOs have been classified as members of families CBM33 and family GH61. But now again, these have been re-classified to "auxiliary activities" (AA) as opposed to their previous classification as GH61 and are found in the AA families 9-11 and 13 (Lombard et al., 2014).

Mhuantong et al. (2015) performed the metagenomic survey of sugarcane bagasse metagenome and showed the presence of GH61 family auxiliary enzymes (AA1, AA3, and AA9). Similarly, Verastegui et al. (2014) used DNA stable-isotope probing (DNA-SIP) to evaluate the functionally active soil bacterial communities and their glycoside hydrolase genes from disparate Canadian soils. This functional annotation of metagenome also displayed the presence of GH61 auxiliary enzymes. The presence of these auxiliary enzymes in metagenome may help to initiate new ideas on the mechanism of enzymatic conversion of cellulosic biomass. The gained knowledge about this newly characterized protein would improve the overall hydrolytic potential of enzyme systems.

It is also noteworthy that the well-developed industrial production organism previously known as $C$. lucknowense $\mathrm{C} 1$ was recently reclassified as $M$. thermophila (Visser et al., 2011) expressing surprisingly higher LPMOs. It possesses higher number of LPMOs genes than any other potent cellulase producers such as T. reesei or A. niger (Table 3). A. nidulans also possesses high number of LPMOs genes but usually not all are expressed in their natural forms and thus, need to be expressed. AN3046, an AA9 LPMO in A. nidulans which is active on cellulose, was cloned in protein 
Table 3.

Cellulase or cellulase encoding genes present in microorganisms.

\begin{tabular}{|c|c|c|}
\hline Microorganisms & Cellulase/genes & References \\
\hline Trichoderma reesei & $\begin{array}{l}2 \mathrm{CBHs}, 8 \mathrm{EGs}, 7 \text { BGLs, } 16 \\
\text { hemicellulases, } 9 \text { LPMOs genes }\end{array}$ & $\begin{array}{l}\text { Aro et al. (2005) } \\
\text { Törrönen et al. (1994) }\end{array}$ \\
\hline Humicola insolens & 2 CBHs,5 EGs lacking CBM & Schulein (1997) \\
\hline Nerospora crassa & $3 \mathrm{CBHs}, 4 \mathrm{EGs}$, and 1 BGLs & Yazdi et al. (1990) \\
\hline Penicillium decumbens & $3 \mathrm{CBHs}, 11 \mathrm{EGs}$, and $11 \mathrm{BGLs}$ & Liu et al. (2013b) \\
\hline Myceliophthora thermophila & $\begin{array}{l}8 \text { EGs, } 7 \text { CBHs, } 9 \text { BGLs, } 25 \\
\text { LPMOs genes }\end{array}$ & Karnaouri et al. (2014b) \\
\hline Aspergillus niger & $\begin{array}{l}2 \text { CBHs, } 2 \text { EGs, } 5 \text { BGLs, } 7 \\
\text { LPMOs genes }\end{array}$ & $\begin{array}{l}\text { de Vries and Visser (2001) } \\
\text { Singhania et al. (2011) }\end{array}$ \\
\hline Clostridium thermocellum & 12 endo and exo cellulases & Bayer et al. (1999) \\
\hline
\end{tabular}

expressing vector (pEXPYR) by ligation free cloning (Jagadeeswaran et al., 2016). Mass spectrometric analysis was performed and it was observed that the enzyme was active on hemicellulose xyloglucan. The AN3046 LPMO synergistically degraded sorghum stover with other hydrolases (Jagadeeswaran et al., 2016). M. thermophila produces thermostable cellulase with higher G:C content in the protein coding genes suggesting the potential adaptability to higher temperatures. Approximately $75 \%$ of $M$. thermophila codons have a higher GC content at the third nucleotide position (GC3) compared with the corresponding mesophilic counterpart (Berka et al., 2011). Enzymes from thermophillic strain when expressed in mesophillic host tend to retain their thermostable properties (Berka et al., 1998; Murray et al., 2004), hence it would be excellent to clone and express heterologous thermophillic cellulase into fast and uniform growing fungal strain which could be less viscous when grown in tank fermenter. $M$. thermophila has been genetically modified and employed for industrial cellulase production by Dyadic due to its capacity of producing $100 \mathrm{~g} / \mathrm{L}$ protein as well as better efficiency of the enzyme.

\section{Conclusions}

There is no doubt that the cost of second-generation bioethanol can only be reduced when the cost component of cellulases be reduced. There have been combined efforts globally on improving the process parameters, bioengineering as well as improving strains. Strain improvement via mutation has been successfully employed on industrial cellulase producing strains, however, the process is quite uncertain and lengthy. Whole genome sequences of important cellulase producing fungal strains, and knowledge of their genetic functions have paved the way for successful targeted modifications. Genetic engineering of robust industrial strains has enabled a single strain to produce repertoire of cellulases depicting high saccharification efficiency of biomass. Targeted modifications at gene sequences of promoter, catabolite repressor, transcriptional factor, and enzymes (e.g., BGL, EG, CBH, xylanase, auxiliary enzymes, etc.), have led to development of the current cellulase producing status and the next steps next steps should be focused on crossing the economic barriers for economically-feasible second-generation bioethanol production. Though genetic modification is a powerful technique to obtain a higher and efficient cellulase producing strain; still, discovery of novel potential cellulase producers should remain a priority as hidden treasures of nature are hard to predict.

\section{Acknowledgement}

Authors RRS and MA would like to acknowledge the Department of Biotechnology, Govt. of India, for 'DBT- Bioscience Energy Overseas Fellowship' and 'Indian Oil Corporation Limited, R\&D Centre' for providing working space.

\section{References}

[1] Adney, W.S., Jeoh, T., Beckham, G.T., Chou, Y.C., Baker, J.O. Michener, W., Brunecky, R., Himmel, M.E., 2009. Probing the role of $N$ linked glycans in the stability and activity of fungal cellobiohydrolases by mutational analysis. Cellulose. 16(4), 699-709.
[2] Adsul, M.G., Ghule, J.E., Shaikh, H., Singh, R., Bastawde, K.B. Gokhale, D.V., Varma, A.J., 2005. Enzymatic hydrolysis of delignified bagasse polysachharides. Carbohydr. Polym. 62(1), 6-10.

[3] Adsul, M.G., Bastawde, K.B., Varma, A.J., Gokhale, D.V., 2007. Strain improvement of Penicillium janthinellum NCIM 1171 for increased cellulase production. Bioresour. Technol. 98(7), 1467 1473

[4] Andberg, M., Penttilä, M., Saloheimo, M., 2015. Swollenin from Trichoderma reesei exhibits hydrolytic activity against cellulosic substrates with features of both endoglucanases and cellobiohydrolases. Bioresour. Technol. 181, 105-113.

[5] Aro, N., Pakula, T., Penttila, M., 2005. Transcriptional regulation of plant cell wall degradation by filamentous fungi. FEMS Microbiol. Rev. 29(4), 719-739.

[6] Bayer, E.A., Chanzy, H., Lamed, R., Shoham, Y., 1998. Cellulose, cellulases and cellulosomes. Curr. Opin. Struct. Biol. 8(5), 548-557.

[7] Beckham, G.T., Dai, Z., Matthews, J.F., Momany, M., Payne, C.M., Adney, W.S., Baker, S.E., Himmel, M.E., 2012. Harnessing glycosylation to improve cellulase activity. Curr. Opin. Biotechnol. 23(3), 338-345.

[8] Berka, R.M., Rey, M.W., Brown, K.M., Byun, T., Klotz, A.V., 1998 Molecular characterization and expression of a phytase gene from the thermophilic fungus Thermomyces lanuginosus. Appl. Environ. Microbiol. 64(11), 4423-4427.

[9] Berka, R.M., Grigoriev, I.V., Otillar, R., Salamov, A., Grimwood, J. Reid, I., Ishmael, N., John, T., Darmond, C., Moisan, M.C., Henrissat, B., Coutinho, P.M., Lombard, V., Natvig, D.O., Lindquist, E., Schmutz, J., Lucas, S., Harris, P., Powlowski, J., Bellemare, A., Taylor, D., Butler, G., de Vries, R.P., Allijn, I.E., van den Brink, J., Ushinsky, S., Storms, R., Powell, A.J., Paulsen, I.T., Elbourne, L.D.H., Backer, S.E., Magnuson, J., LaBoissiere, S., Clutterbuck, A.J., Martinez, D., Wogulis, M., de Leon, A.L., Rey, M.W., Tsang, A., 2011. Comparative genomic analysis of the thermophilic biomassdegrading fungi Myceliophthora thermophila and Thielavia terrestris. Nat. Biotechnol. 29(10), 922-927.

[10] Bommarius, A.S., Sohn, M., Kang, Y., Lee, J.H., Realff, M.J., 2014. Protein engineering of cellulases. Curr. Opin. Biotechnol. 29, 139 145.

[11] Bulakhov, A.G., Volkov, P.V., Rozhkova, A.M., Gusakov, A.V., Nemashkalov, V.A., Satrutdinov, A.D., Sinitsyn, A.P., 2017. Using an inducible promoter of a gene encoding Penicillium verruculosum glucoamylase for production of enzyme preparations with enhanced cellulase performance. PLoS ONE. 12(1), p.e0170404.

[12] Chand, P., Aruna, A., Maqsood, A.M., Rao, L.V., 2005. Novel mutation method for increased cellulase production. J. Appl. Microbiol. 98(2), 318-323

[13] Coradetti, S.T., Craig, J.P., Xiong, Y., Shock, T., Tian, C., Glass, N.L., 2012. Conserved and essential transcription factors for cellulase gene expression in ascomycete fungi. Proc. Natl. Acad. Sci. USA 109(19), 7397-7402

[14] Dalby, P.A., 2007. Engineering enzymes for biocatalysis. Recent Pat. Biotechnol. 1(1), 1-9.

[15] Dashtban, M., Schraft, H., Qin. W., 2009. Fungal bioconversion of lignocellulosic residues; opportunities \& perspectives. Int. J. Biol. Sci. 5(6), 578-595

[16] de Vries, R.P., Visser, J., 2001. Aspergillus enzymes involved in degradation of plant cell wall polysaccharides. Microbiol. Mol. Boil. Rev. 65(4), 497-522.

[17] Dotsenko, G.S., Gusakov, A.V., Rozhkova, A.M., Korotkova, O.G. Sinitsyn, A.P., 2015. Heterologous $\beta$-glucosidase in a fungal cellulase system: comparison of different methods for development of multienzyme cocktails. Process Biochem. 50(8), 1258-1263.

[18] Dotsenko, A.S., Gusakov, A.V., Volkov, P.V., Rozhkova, A.M. Sinitsyn, A.P., 2016. N-linked glycosylation of recombinant cellobiohydrolase I (Ce17A) from Penicillium verruculosum and its effect on the enzyme activity. Biotechnol. Bioeng. 113(2), 283-291.

[19] Durand, H., Clanet, M., 1988. Genetic improvement of Trichoderma reesei for large-scale cellulase production. Enzyme Microb. Technol. 10(6), 341-346. 
[20] Eibinger, M., Ganner, T., Bubner, P., Rošker, S., Kracher, D., Haltrich, D., Ludwig, R., Plank, H., Nidetzky, B., 2014. Cellulose surface degradation by a lytic polysaccharide monooxygenase and its effect on cellulase hydrolytic efficiency. J. Biol. Chem. 289(52), 35929-35938.

[21] Eveleigh, D.E., Montenecourt, B.S., 1979. Increasing yields of extracellular enzymes. Adv. Appl. Microbiol. 25, 57-74.

[22] Fujii, T., Inoue, H., Ishikawa, K., 2013. Enhancing cellulase and hemicellulase production by genetic modification of the carbon catabolite repressor gene, creA, in Acremonium cellulolyticus. AMB Expre. 3(1), 73.

[23] Fukuda, H., Kondo, A., Tamalampudi, S., 2009. Bioenergy: sustainable fuels from biomass by yeast and fungal whole-cell biocatalysts. Biochem. Eng. J. 44(1), 2-12.

[24] Garvey, M., Klose, H., Fischer, R., Lambertz, C., Commandeur, U., 2013. Cellulases for biomass degradation: comparing recombinant cellulase expression platforms. Trends Biotechnol. 31(10), 581-593.

[25] Gilkes, N.R., Henrissat, B., Kilburn, D.G., Miller Jr, R.C., Warren, R.A., 1991. Domains in microbial beta-1,4-glycanases: sequence conservation, function, and enzyme families. Microbiol. Rev. 55(3), 303-315.

[26] Gourlay, K., Hu, J., Arantes, V., Andberg, M., Saloheimo, M., Penttilä, M., Saddler, J., 2013. Swollenin aids in the amorphogenesis step during the enzymatic hydrolysis of pretreated biomass. Bioresour. Technol. 142, 498-503.

[27] Greene, E.R., Himmel, M.E., Beckham, G.T., Tan, Z., 2015. Glycosylation of cellulases: engineering better enzymes for biofuels. Adv. Carbohyd. Chem. Biochem. 72, 63-112.

[28] Guangtao, Z., Hartl, L., Schuster, A., Polak, S., Schmoll, M., Wang, T., Seidl, V., Seiboth, B., 2009. Gene targeting in a nonhomologous end joining deficient Hypocrea jecorina. J. Biotechnol. 139(2), 146-151.

[29] Gusakov, A.V., Salanovich, T.N., Antonov, A.I., Ustinov, B.B., Okunev, O.N., Burlingame, R., Emalfarb, M., Baez, M., Sinitsyn, A.P., 2007. Design of highly efficient cellulase mixtures for enzymatic hydrolysis of cellulose. Biotechnol. Bioeng. 97(5), 1028-1038.

[30] Gusakov, A.V., 2011. Alternatives to Trichoderma reesei in biofuel production. Trends Biotechnol. 29(9), 419-425.

[31] Gusakov, A.V., 2013. Cellulases and hemicellulases in the 21st century race for cellulosic ethanol. Biofuels. 4(6), 567-569.

[32] Gusakov, A.V., 2014. Comment on "revealing nature's cellulase diversity: the digestion mechanism of Caldicellulosiruptor bescii CelA". Science. 344(6184), 578.

[33] Gusakov, A.V., Dotsenko, A.S., Rozhkova, A.M., Sinitsyn, A.P., 2017. $N$-linked glycans are an important component of the processive machinery of cellobiohydrolases. Biochimie. 132, 102-108.

[34] Harkki, A., Mäntylä, A., Penttilä, M., Muttilainen, S., Bühler, R., Suominen, P., Knowles, J., Nevalainen, H., 1991. Genetic engineering of Trichoderma to produce strains with novel cellulase profiles. Enzyme Microb. Technol. 13(3), 227-233.

[35] Harris, P.V., Welner, D., McFarland, K.C., Re, E., Navarro Poulsen, J.C., Brown, K., Salbo, R., Ding, H., Vlasenko, E., Merino, S., Xu, F., Cherry, J., Larsen, S., Legglo, L.L., 2010. Stimulation of lignocellulosic biomass hydrolysis by proteins of glycoside hydrolase family 61: structure and function of a large, enigmatic family. Biochemistry. 49(15), 3305-3316.

[36] Hu, J., Arantes, V., Saddler, J.N., 2011. The enhancement of enzymatic hydrolysis of lignocellulosic substrates by the addition of accessory enzymes such as xylanase: is it an additive or synergistic effect. Biotechnol. Biofuels. 4(1), 36-48.

[37] Hu, Y., Liu, G., Li, Z., Qin, Y., Qu, Y., Song, X., 2013. G protein-cAMP signaling pathway mediated by PGA3 plays different roles in regulating the expressions of amylases and cellulases in Penicillium decumbens. Fungal Genet. Biol. 58-59, 62-70.

[38] Ilmen, M., Saloheimo, A.N.U., Onnela, M.L., Penttila, M.E., 1997. Regulation of cellulase gene expression in the filamentous fungus Trichoderma reesei. Appl. Environ. Microbiol. 63(4), 1298-1306.

[39] Isaac, G.S., Abu-Tahon, M.A., 2015. Enhanced alkaline cellulases production by the thermohalophilic Aspergillus terreus AUMC 10138 mutated by physical and chemical mutagens using corn stover as substrate. Braz. J. Microbiol. 46(4), 1269-1277.

[40] Jagadeeswaran, G., Gainey, L., Prade, R., Mort, A.J., 2016. A family of AA, lytic polysaccharide monooxygenases in Aspergillus nidulans is differentially regulated by multiple substrates and at least one is active on cellulose and xyloglucan. Appl. Microbiol. Biotechnol. 100(10), 4535-4547.

[41] Javed, M.M., Haq, I., Mariyam, I., 2011. Multistep mutagenesis for the over-expression of cellulase in Humicola insolens. Pak. J. Bot. 43(1), 669-677.

[42] Jeoh, T., Michener, W., Himmel, M.E., Decker, S.R., Adney, W.S. 2008. Implications of cellobiohydrolase glycosylation for use in biomass conversion. Biotechnol. Biofuels. 1(1), 10.

[43] Karnaouri, A.C., Topakas, E., Christakopoulos, P., 2014a. Cloning, expression, and characterization of a thermostable $\mathrm{GH}$ endoglucanase from Myceliophthora thermophila capable of highconsistency enzymatic liquefaction. Appl. Microbiol. Biotechnol. 98(1), 231-242.

[44] Karnaouri, A., Topakas, E., Antonopoulou, I., Christakopoulos, P., 2014b. Genomic insights into the fungal lignocellulolytic system of Myceliophthora thermophila. Front. Microbiol. 5, 281.

[45] Kotchoni, O.S., Shonukan, O.O., Gachomo, W.E., 2003. Bacillus pumilus BpCRI 6, a promising candidate for cellulase production under conditions of catabolite repression. Afr. J. Biotechnol. 2(6), 140-146.

[46] Kovacs, K., Megyeri, L., Szakacs, G., Kubicek, C.P., Galbe, M., Zacchi, G., 2008. Trichoderma atroviride mutants with enhanced production of cellulase and $\beta$-glucosidase on pretreated willow. Enzyme Microb. Technol. 43(1), 48-55.

[47] Kuhad, R.C., Kumar, M., Singh, A., 1994. A hypercellololytic mutant of Fusarium oxysporum. Lett. Appl. Microbiol. 19(5), 397-400.

[48] Levasseur, A., Drula, E., Lombard, V., Coutinho, P.M., Henrissat, B. 2013. Expansion of the enzymatic repertoire of the CAZy database to integrate auxiliary redox enzymes. Biotechnol. Biofuels. 6(1), 41

[49] Li, X.H., Yang, H.J., Roy, B., Park, E.Y., Jiang, L.J., Wang, D., Miao, Y.G., 2010. Enhanced cellulase production of the Trichoderma viride mutated by microwave and ultraviolet. Microbiol. Res. 165(3), 190198.

[50] Li, J., Liu, G., Chen, M., Li, Z., Qin, Y., Qu, Y., 2013. Cellodextrin transporters play important roles in cellulase induction in the cellulolytic fungus Penicillium oxalicum. Appl. Microbiol. Biotechnol. 97(24), 10479-10488.

[51] Liu, G., Zhang, L., Qin, Y., Zou, G., Li, Z., Yan, X., Wei, X., Chen, M., Chen, L., Zheng, K., Zhang, J., Ma, L., Li, J., Liu, R., Xu, H., Bao, X., Fang, X., Wang, L., Zhong, Y., Lio, W., Zheng, H., Wang, S., Wang, C., Xun, C., Zhao, G.P., 2013a. Long-term strain improvements accumulate mutations in regulatory elements responsible for hyper-production of cellulolytic enzymes. Sci. Rep. 3 , 1569 .

[52] Liu, G., Zhang, L., Wei, X., Zou, G., Qin, Y., Ma, L., Li, J., Zheng, H., Wang, S., Wang, C., Xun, L., Zhao, G.P., Zhou, Z., Qu, Y., 2013 b. Genomic and secretomic analyses reveal unique features of the lignocellulolytic enzyme system of Penicillium decumbens. PloS ONE. 8(2), p.e55185.

[53] Lombard, V., Ramulu, H.G., Drula, E., Coutinho, P.M., Henrissat, B. 2014. The carbohydrate-active enzymes database (CAZy) in 2013. Nucleic Acids Res. 42(D1), D490-D495.

[54] Lynd, L.R., Weimer, P.J., van Zyl, W.H., Pretorius, I.S., 2002 Microbial cellulose utilization: fundamentals and biotechnology. Microbiol. Mol. Biol. Rev. 66(3), 506-577.

[55] Ma, L., Zhang, J., Zou, G., Wang, C., Zhou, Z., 2011. Improvement of cellulase activity in Trichoderma reesei by heterologous expression of a beta-glucosidase gene from Penicillium decumbens. Enzyme Microb. Technol. 49(4), 366-371.

[56] Mahadevan, S.A., Wi, S.G., Lee, D.S., Bae, H.J., 2008. Site-directed mutagenesis and CBM engineering of Cel5A (Thermotoga maritima). FEMS Microbiol. Lett. 287(2), 205-211.

[57] Mandels, M., Weber, J., Parizek, R., 1971. Enhanced cellulase production by a mutant of Trichoderma viride. Appl. Microbiol. 21(1), 152-154.

[58] Martinez, D., Berka, R.M., Henrissat, B., Saloheimo, M., Arvas, M. Baker, S.E., Chapman, J., Chertkov, O., Coutinho, P.M., Cullen, D., Danchin, E.G.J., Grigoriev, I.V., Harris, P., Jackson, M., Kubicek, C.P., Han, C.S., Ho, I., Larrondo, L.F., Lopez de Leon, A., Magnuson, J.K., Merino, S., Misra, M., Nelson, B., Putnam, N., Robbertse, B., 
Salamov, A.A., Schmoll, M., Terry, A., Thayer, N., WesterholmParvinen, A., Schoch, C.L., Yao, J., Barbote, R., Nelson, M.A., Detter, C., Bruce, D., Kuske, C.R., Xie, G., Richardson, P., Rokhsar, D.S., Lucas, S.M., Rubin, E.M., Dunn-Coleman, N., Ward, M., Brettin, T.S., 2008. Genome sequencing and analysis of the biomass-degrading fungus Trichoderma reesei (syn. Hypocrea jecorina). Nat. Biotechnol. 26(5), 553-560.

[59] Mathew, G.M., Sukumaran, R.K., Singhania, R.R., Pandey, A., 2008. Progress in research on fungal cellulases for lignocellulose degradation. J. Sci. Ind. Res. 67(11), 898-907.

[60] McFarland, K.C., Ding, H., Teter, S., Vlasenko, E., Xu, F., Cherry, J., 2007. Development of improved cellulase mixtures in a single production organism, in: Eggleston, G., Vercellotti, J.R. (Eds.), Industrial Application of Enzymes on Carbohydrate-Based Material. ACS Symposium Series, American Chemical Society. 2, 19-31.

[61] Mhuantong, W., Charoensawan, V., Kanokratana, P., Tangphatsornruang, S., Champreda, V., 2015. Comparative analysis of sugarcane bagasse metagenome reveals unique and conserved biomassdegrading enzymes among lignocellulolytic microbial communities. Biotechnol. Biofuels. 8(1), 1-17.

[62] Murray, P., Aro, N., Collins, C., Grassick, A., Penttilä, M., Saloheimo, M., Tuohy, M., 2004. Expression in Trichoderma reesei and characterisation of a thermostable family $3 \beta$-glucosidase from the moderately thermophilic fungus Talaromyces emersonii. Protein Expr. Purif. 38(2), 248-257.

[63] Nakari-Setälä, T., Paloheimo, M., Kallio, J., Vehmaanperä, J., Penttilä, M., Saloheimo, M., 2009. Genetic modification of carbon catabolite repression in Trichoderma reesei for improved protein production. Appl. Environ. Microbiol. 75(14), 4853-4860.

[64] Ohmiya, K., Sakka, K., Karita, S., Kimura, T., 1997. Structure of cellulases and their application. Biotechnol. Gene. Eng. Rev. 14(1), 365414.

[65] Payne, C.M., Resch, M.G., Chen, L., Crowley, M.F., Himmel, M.E., Taylor II, L.E., Sandgren, M., Ståhlberg, J., Stals, I., Tan, Z., Beckham, G.T., 2013. Glycosylated linkers in multimodular lignocellulosedegrading enzymes dynamically bind to cellulose. Proc. Natl. Acad. Sci. U.S.A. 110(36), 14646-14651.

[66] Penttilä, M., Nevalainen, H., Rättö, M., Salminen, E., Knowles, J., 1987. A versatile transformation system for the cellulolytic filamentous fungus Trichoderma reesei. Gene. 61(2), $155-164$.

[67] Peterson, R., Nevalainen, H., 2012. Trichoderma reesei RUT-C30-thirty years of strain improvement. Microbiology. 158(1), 58-68.

[68] Mayorga-Reyes, L., Ponce-Noyola, T., 1998. Isolation of a hyperxylanolytic cellulomonas xavigena mutant growing on continuous culture on sugar cane bagasse. Biotechnol. Lett. 20(5), 443-446.

[69] Sakka, K., Kimura, T., Karita, S., Ohmiya, K., 2000. Molecular breeding of cellulolytic microbes, plants, and animals for biomass utilization. J. Biosci. Bioeng. 90(3), 227-233.

[70] Saini, J.K., Patel, A.K., Adsul, M., Singhania, R.R., 2016. Cellulase adsorption on lignin: A roadblock for economic hydrolysis of biomass. Renew. Energ. 98, 29-42.

[71] Saloheimo, M., Paloheimo, M., Hakola, S., Pere, J., Swanson, B., Nyyssonen, E., Bhatia, A., Ward, M., Penttilä, M., 2002. Swollenin, a Trichoderma reesei protein with sequence similarity to the plant expansins, exhibits disruption activity on cellulosic materials. Eur. J. Biochem. 269(17), 4202-4211

[72] Schulein, M., 1997. Enzymatic properties of cellulases from Humicola insolens. J. Biotechnol. 57(1-3), 71-81.

[73] Schwarz, W., 2001. The cellulosome and cellulose degradation by anaerobic bacteria. Appl. Microbiol. Biotechnol. 56(5), 634-649.

[74] Singhania, R.R., Sukumaran, R.K., Patel, A.K., Larroche, C., Pandey, A., 2010. Advancement and comparative profiles in the production technologies using solid-state and submerged fermentation for microbial cellulases. Enzyme Microb. Technol. 46(7), 541-549.

[75] Singhania, R.R., Sukumaran, R.K., Rajasree, K.P., Mathew, A., Gottumukkala, L., Pandey, A., 2011. Properties of a major $\beta$-glucosidaseBGL1 from Aspergillus niger NII-08121 expressed differentially in response to carbon sources. Process Biochem. 46(7), 1521-1524.
[76] Singhania, R.R., Patel, A.K., Sukumaran, R.K., Larroche, C., Pandey, A., 2013. Role and significance of beta-glucosidases in the hydrolysis of cellulose for bioethanol production. Bioresour. Technol. 127, 500507.

[77] Singhania, R.R., Patel, A., Pandey, A., Gnasoundou, E., 2017 Genetic modification: a tool for enhancing beta-glucosidase production for biofuel application. Bioresour. Technol. DOI: 10.1016/j.biortech.2017.05.126

[78] Sriprang, R., Asano, K., Gobsuk, J., Tanapongpipat, S., Champreda, V., Eurwilaichitr, L., 2006. Improvement of thermostability of funga xylanase by using site-directed mutagenesis. J. Biotechnol. 126(4), 454-462.

[79] Steiger, M.G., Vitikainen, M., Uskonen, P., Brunner, K., Adam, G., Pakula, T., Penttilä, M., Saloheimo, M., Mach, R.L., Mach-Aigner, A.R., 2011. Transformation system for Hypocrea jecorina (Trichoderma reesei) that favors homologous integration and employs reusable bidirectionally selectable markers. Appl. Environ. Microbiol. 77(1), 114-121

[80] Sukumaran, R.K., Pandey, A. (Ed.), 2008. Bioethanol from lignocellulosic biomass-part II production of cellulases and hemicellulases. Plant-based Biofuels. CRC Press, Taylor \& Francis. $141-157$

[81] Törrönen, A., Harkki, A., Rouvinen, J., 1994. Three-dimensional structure of endo-1,4-beta-xylanase II from Trichoderma reesei: two conformational states in the active site. EMBO J. 13(11), 2493-2501.

[82] Trudeau, D.L., Lee, T.M., Arnold, F.H., 2014. Engineered thermostable fungal cellulases exhibit efficient synergistic cellulose hydrolysis at elevated temperatures. Biotechnol. Bioeng. 111(12), 2390-2397

[83] Uusitalo, J.M., Nevalainen, K.M.H., Harkki, A.M., Knowles, J.K.C., Penttilä, M.E., 1991. Enzyme production by recombinant Trichoderma reesei strains. J. Biotechnol. 17(1), 35-49.

[84] Veen, P.V.D., Ruijter, J.G.G., Visser, J., 1995. An extreme creA mutation in Aspergillus nidulans has severe effects on D-glucose utilization. Microbiology. 141(9), 2301-2306.

[85] Verastegui, Y., Cheng, J., Engel, K., Kolczynski, D., Mortimer, S., Lavigne, J., Montalibet, J., Romantsov, T., Hall, M., McConkey, B.J., Rose, D.R., Tomashek, J.J., Scott, B.R., Charles, T.C., Neufeld, J.D., 2014. Multisubstrate isotope labeling and metagenomic analysis of active soil bacterial communities. MBio 5(4), p.e01157-14.

[86] Volynets, B., Dahman, Y., 2011. Assessment of pretreatments and enzymatic hydrolysis of wheat straw as a sugar source for bioprocess industry. Int. J. Eng. Environ. 2(3), 427-446.

[87] Voutilainen, S.P., Puranen, T., Siika-aho, M., Lappalainen, M., Alapuranen, M., Kallio, J., Hooman, S., Viikari, L., Vehmaanpera, J. Koivula, A., 2008. Cloning, expression, and characterization of nove thermostable family 7 cellobiohydrolases. Biotechnol. Bioeng. 101(3), 515-528.

[88] Vu, V.H., Pham, T.A., Kim, K., 2009. Fungal strain improvement for cellulase production using repeated and sequential mutagenesis. Mycobiology. 37(4), 267-271.

[89] Vu, V.H., Pham, T.A., Kim, K., 2011. Improvement of fungal cellulase production by mutation and optimization of solid state fermentation. Mycobiology. 39(1), 20-25

[90] Wang, H., Jones, R.W., 1997. Site-directed mutagenesis of a fungal $\beta-1,4$-endoglucanase increases the minimum size required for the substrate. Appl. Microbiol. Biotechnol. 48(2), 225-231.

[91] Westereng, B., Cannella, D., Agger, J.W., Jorgensen, H., Andersen, M.L., Eijsink, V.G.H., Felby, C., 2015. Enzymatic cellulose oxidation is linked to lignin by long range electron transfer. Sci. Rep. 5, 18561.

[92] Wood, T.M., McCrae, S.I., Wilson, C.A., Bhat, K.M., Gow, L.A., 1988. Aerobic and anaerobic fungal cellulases, with special reference to their mode of attack on crystalline cellulose. in: Aubert, J.P., Beguin, P., Millet, J. (Eds.), Biochemistry and genetics of cellulose degradation. Academic Press, London. 31-52.

[93] Yao, G., Wu, R., Kan, Q., Gao, L., Liu, M., Yang, P., Du, J., Li, Z., Qu, Y., 2016. Production of a high-efficiency cellulase complex via $\beta$-glucosidase engineering in Penicillium oxalicum. Biotechnol. Biofuels. 9, 78 . 
[94] Yao, G., Li, Z., Gao, L., Wu, R., Kan, Q., Liu, G., Qu, Y., 2015. Redesigning the regulatory pathway to enhance cellulase production in Penicillium oxalicum. Biotechnol. Biofuels. 8(1), 71.
[95] Yazdi, M.T., Woodward, J.R., Radford, A., 1990. Cellulase production by Neurospora crassa: the enzyme of the complex and their regulation. Enzyme Microb. Technol. 12(2), 116-119. 